\title{
Effect of Cutting Modes and Tool Wear on the Microhardness of the Surface Layer after Face Milling of Structural and Stainless Steels
}

\author{
Alexey Popov, Sergei Babak \\ Department of Machining and Assembly, Faculty of Mechanical Engineering, Technical University of Liberec \\ 461 17, Studentská 1402/2, Liberec 1, Czech Republic \\ E-mail: alespopov@yandex.ru,babakss@mail.ru
}

\begin{abstract}
The quality of the surface layer of the parts directly affects the life cycle of these parts within machine components. The required surface quality of parts can be secured when keeping a certain operational sequence. Each operation in this sequence affects the final result due to the so-called technological heredity. This means that after each operation it is necessary to achieve certain properties, such as maximum achievable microhardness of the machined surface and residual compressive stresses. This research aims to study the management of machined surface quality after face milling of structural and stainless steels. The laboratory of the Department of Machining and Assembly of the Technical University of Liberec has carried out tests to examine the effect of cutting modes and tool wear on the microhardness of the machined surface after milling.
\end{abstract}

Keywords: Cutting modes, Microhardness, Milling, Surface Integrity, Tool Wear

\section{Introduction}

Machining processes induce plastic deformation under the surface of machined components. The severe plastic deformation creates alteration of microstructure and residual stress in the subsurface of machined component. Cutting conditions and tool wear have appreciable impact on creation and redistribution of residual stresses in the workpiece and also on microhardness of the processed surface.

The problem is that it is not possible to determine microhardness after each technological process under different processing conditions with the help of theoretical methods; therefore it is necessary to experimentally identify microhardness alterations which depend on cutting conditions after various technological processes. The following studies confirm that the world scientific community is interested in studying the quality of the surface layer after using various processing methods. So, for example, the microhardness of the machined surface has been experimentally determined after the turning of titanium alloy Ti-6Al-4V [1], stainless steel ASTM A890Gr6A [2], and nickel alloy Inconel 718 [3]; after the milling of titanium alloy Ti6Al4V [4] and Inconel 718 [5]; after the drilling of nickel based superalloy RR1000 [6], and after the drawing of steels AISI 1045, AISI 12L14, aluminium Al 7075, brass [7], and nickel alloy Inconel 718 [8].

This research is dedicated to determining the effect of cutting modes and tool wear on the microhardness of the surface layer after face milling of structural and stainless steels in order to control the quality of the surface layer in machine parts.

\section{Experimental procedures}

The experiments were carried out by face milling on the milling machine FNG 32 with manual control [10, 11]. The cutter used for milling was a 63-diameter cutter Narex 2460.12. Milling of the constraction steels
$16 \mathrm{MnCr} 5$ (0.19\% C; 0.4\% Si; 1\% Mn; 0.025\% P; 0.035\% $\mathrm{S} ; 1.1 \% \mathrm{Cr} ; 138 \mathrm{HB}), \mathrm{C} 45$ (0.45\% C; $0.8 \% \mathrm{Mn} ; 0.37 \%$ $\mathrm{Si} ; 0.25 \% \mathrm{Cr} ; 0.3 \% \mathrm{Cu} ; 0.3 \% \mathrm{Ni} ; 0.04 \% \mathrm{P} ; 0.04 \% \mathrm{~S} ; 220$ HB) and the stainless steel X20Cr13 $(0.25 \% \mathrm{C} ; 1 \% \mathrm{Si}$; $1.5 \% \mathrm{Mn} ; 0.04 \% \mathrm{P} ; 0.015 \% \mathrm{~S} ; 14 \% \mathrm{Cr} ; 230 \mathrm{HB})$ was performed with the cutting inserts SNUN 120412 of hard alloy 8230 (P20-40) with coating by the company Pramet Tools s. r. o. at a cutting speed of $v_{c}=158-316 \mathrm{~m} / \mathrm{min}$ for $16 \mathrm{MnCr} 5$ and $\mathrm{C} 45, v_{c}=134-268 \mathrm{~m} / \mathrm{min}$ for $\mathrm{X} 20 \mathrm{Cr} 13$, feed $f_{z}=0.025-0.04 \mathrm{~mm} /$ tooth, depth of cut $a_{p}=0.05-0.5$ $\mathrm{mm}$. The experiments were carried out with one insert fixed to the milling cutter.

Due to the complicated process of microhardness measuring, it was not possible to determine the effect of feed by more than $0.04 \mathrm{~mm} /$ tooth. As demonstrated in Fig. 2, even at the feed of $0.05 \mathrm{~mm} /$ tooth the point of the tool gets into the cavities.

The depth of cut was set manually and controlled by an indicator at a scale of $0.002 \mathrm{~mm}$.

For all machining experiments, $5 \%$ solution of water and an emulsion concentrate Zubora Universal was prepared. The cutting fluid concentration was controlled by the refractometer Optech Brix RLC / ATC, characterized by concentration measurement at a range of $0-18 \%$ and accuracy of $0.1 \%$.

Wear of the rear surface VB was measured by using a Brinell Magnifier tool (magnification 24x, accuracy 0.05 $\mathrm{mm}$ ) [11]. New cutting plates had a flank wear VB of 0.03 $\mathrm{mm}$ because they had a cutting edge radius $0.03 \mathrm{~mm}$ [13]. The flank wear VB of the new cutting plates was measured by microscope Carl Zeiss Jena with an accuracy of $0.01 \mathrm{~mm}$.

Before each measurement of microhardness, 5 passes were made under identical conditions. The measurements were carried out using a Zwick 3212 tester on three spots, as indicated in Fig. 2. Five measurements were taken at each spot, after which the average microhardness of the given surface was calculated on the basis of 15 measurements. 


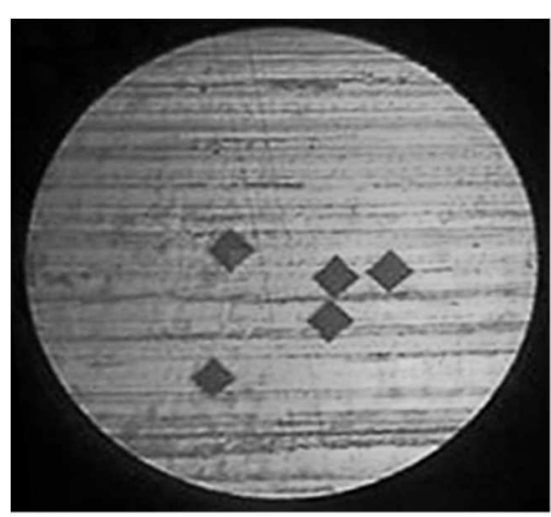

a) $f_{z}=0.025 \mathrm{~mm} /$ tooth

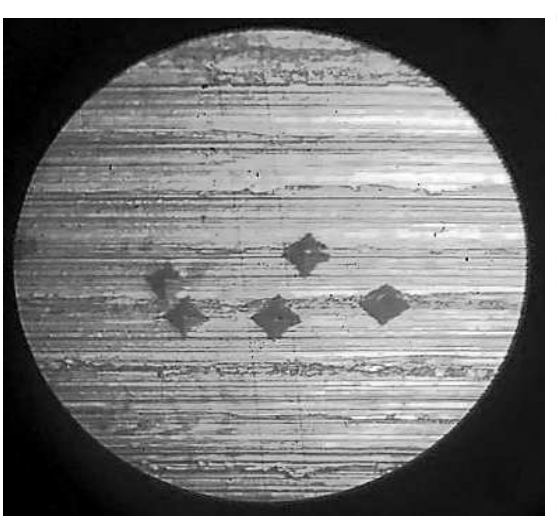

b) $f_{z}=0.04 \mathrm{~mm} /$ tooth

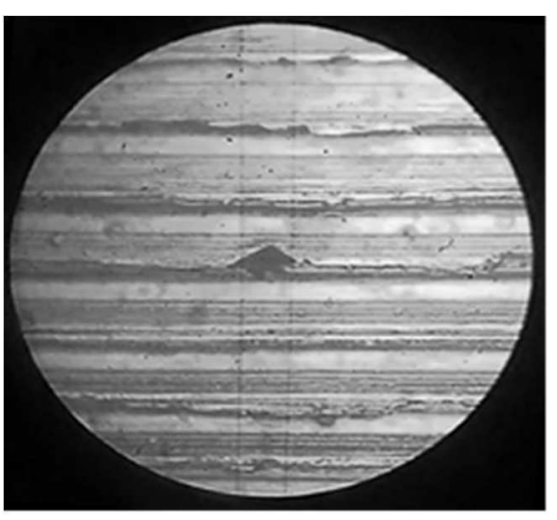

c) $f_{z}=0.05 \mathrm{~mm} /$ tooth

Fig. 1 Measuring the microhardness of the machined surface after face milling with different feeds fz (Magnification: $40 x$ )

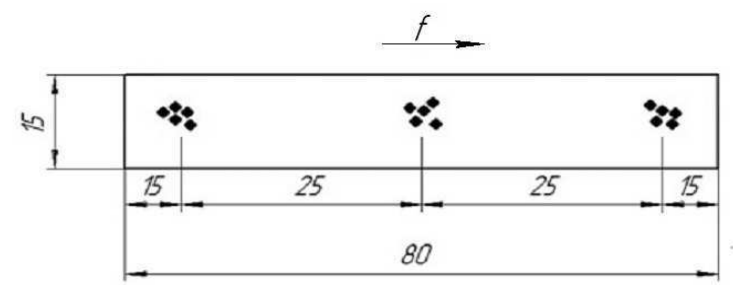

Fig. 2 Measuring diagram of the microhardness of machined surface after face milling

\section{Experimental results and analysis}

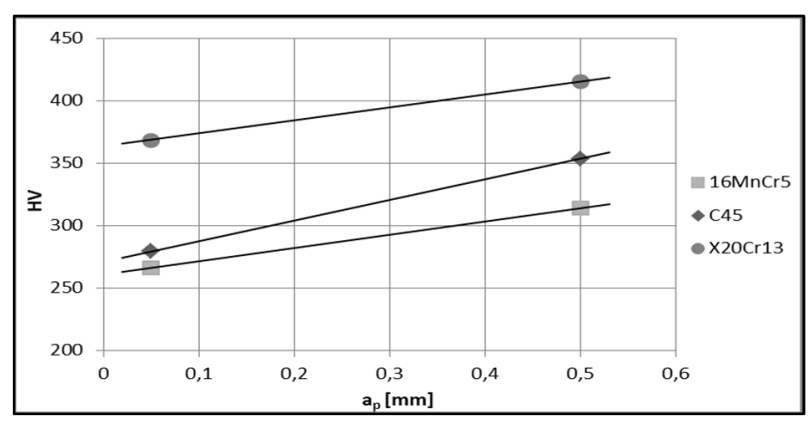

a) $v_{c}=316 \mathrm{~m} / \mathrm{min}(16 \mathrm{MnCr} 5, \mathrm{C45}) ; v_{c}=268 \mathrm{~m} / \mathrm{min}$ (X20Cr13); $f_{z}=0.025 \mathrm{~mm} / \mathrm{tooth} ; \mathrm{VB}=0.03 \mathrm{~mm}$

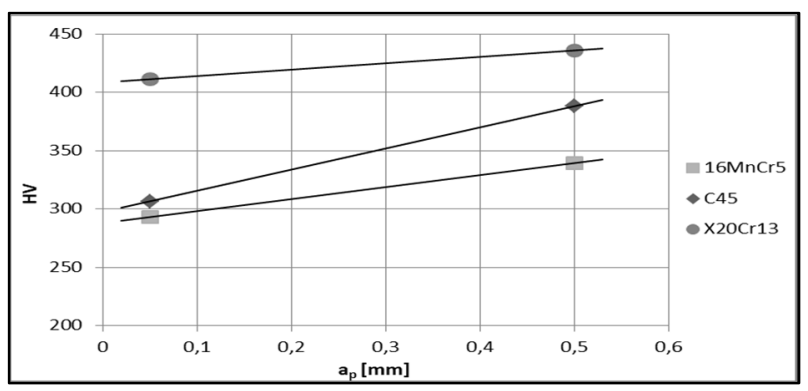

b) $v_{c}=316 \mathrm{~m} / \mathrm{min}(16 \mathrm{MnCr} 5, \mathrm{C45}) ; v_{c}=268 \mathrm{~m} / \mathrm{min}$ (X20Cr13); $f_{z}=0.025 \mathrm{~mm} /$ tooth; $V B=0.44 \mathrm{~mm}$

Fig. 3 Effect of depth of cut $a_{p}$ on the microhardness of the machined surface $\mathrm{HV}$

The tests showed that increasing the depth of cut $a_{p}$ by 10 times, from $0.05 \mathrm{~mm}$ to $0.5 \mathrm{~mm}$, when milling with new cutting inserts ( $\mathrm{VB}=0.03 \mathrm{~mm}$ ) led to an increase in the microhardness of structural steel $16 \mathrm{MnCr} 5$ by $18 \%$, structural steel C45 by $26 \%$ and stainless steel X20Cr 13 by $13 \%$ (Fig. 3a). After milling with worn cutting inserts (VB $=0.44 \mathrm{~mm}$ ), a similar 10-fold increase in the depth of cut led to an increase in the microhardness of structural steel $16 \mathrm{MnCr} 5$ by $16 \%$, structural steel $\mathrm{C} 45$ by $26 \%$ and stainless steel $\mathrm{X} 20 \mathrm{Cr} 13$ by $6 \%$ (Fig. 3b).

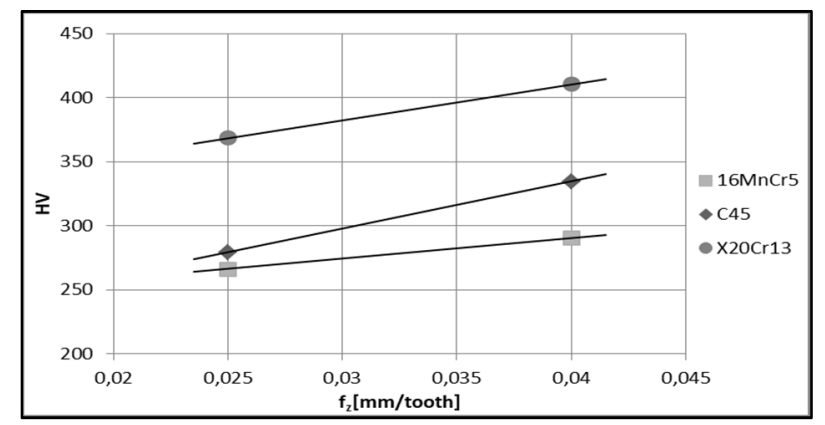

a) $v_{c}=316 \mathrm{~m} / \mathrm{min}(16 \mathrm{MnCr} 5, \mathrm{C45}) ; v_{c}=268 \mathrm{~m} / \mathrm{min}$ $(X 20 C r 13) ; a_{p}=0.05 \mathrm{~mm} ; V B=0.03 \mathrm{~mm}$

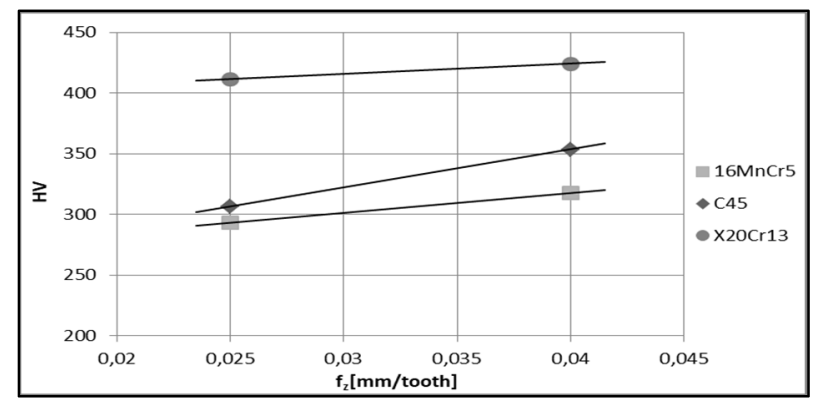

b) $v_{c}=316 \mathrm{~m} / \mathrm{min}(16 \mathrm{MnCr} 5, \mathrm{C45}) ; v_{c}=268 \mathrm{~m} / \mathrm{min}$ (X20Cr13); $a_{p}=0.05 \mathrm{~mm} ; \mathrm{VB}=0.44 \mathrm{~mm}$

Fig. 4 Effect of feed $f_{z}$ on the microhardness of the machined surface $H V$

It was found that the increase in feed $f_{z}$ by $60 \%$, from $0.025 \mathrm{~mm} /$ tooth to $0.04 \mathrm{~mm} /$ tooth, when milling with new cutting inserts $(\mathrm{VB}=0.03 \mathrm{~mm}$ ) led to an increase in the microhardness of structural steel $16 \mathrm{MnCr} 5$ by $9 \%$, structural steel C45 by $20 \%$ and stainless steel X20Cr13 by $11 \%$ (Fig. 4a). After milling with worn cutting inserts $(\mathrm{VB}=0.44 \mathrm{~mm})$, a similar increase in feed by $60 \%$ led to an increase in the microhardness of structural steel $16 \mathrm{MnCr} 5$ by $8 \%$, structural steel $\mathrm{C} 45$ by $15 \%$ and stainless steel X20Cr13 by 3\% (Fig. 4b). 


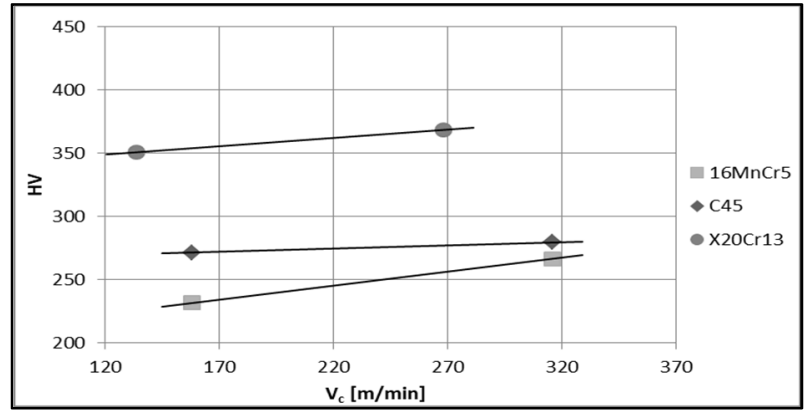

a) $f_{z}=0.025 \mathrm{~mm} /$ tooth; $a_{p}=0.05 \mathrm{~mm} ; \mathrm{VB}=0.03 \mathrm{~mm}$

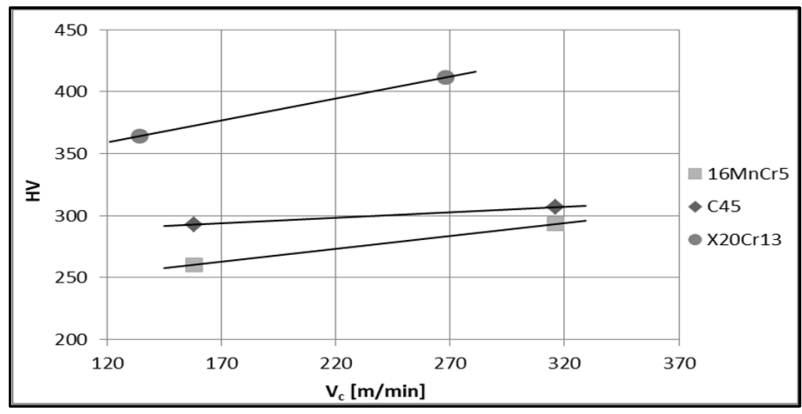

b) $f_{z}=0.025 \mathrm{~mm} /$ tooth; $a_{p}=0.05 \mathrm{~mm} ; V B=0.44 \mathrm{~mm}$

Fig. 5 Effect of cutting speed $v_{c}$ on the microhardness of the machined surface $H V$

A 2-fold increase in the cutting speed of $v_{c}$, from $158 \mathrm{~m} / \mathrm{min}$ to $316 \mathrm{~m} / \mathrm{min}$, led to an increase in the microhardness of structural steel $16 \mathrm{MnCr} 5$ by $15 \%$, structural steel $\mathrm{C} 45$ by $3 \%$ after milling with new cutting inserts $(\mathrm{VB}=0.03 \mathrm{~mm})$ (Fig. 5a). A 2-fold increase in the cutting speed of $v_{c}$, from $134 \mathrm{~m} / \mathrm{min}$ to $268 \mathrm{~m} / \mathrm{min}$, led to an increase in microhardness of stainless steel X20Cr13 by $5 \%$ after milling with new cutting inserts $(\mathrm{VB}=0.03 \mathrm{~mm}$ ) (Fig. 5a).

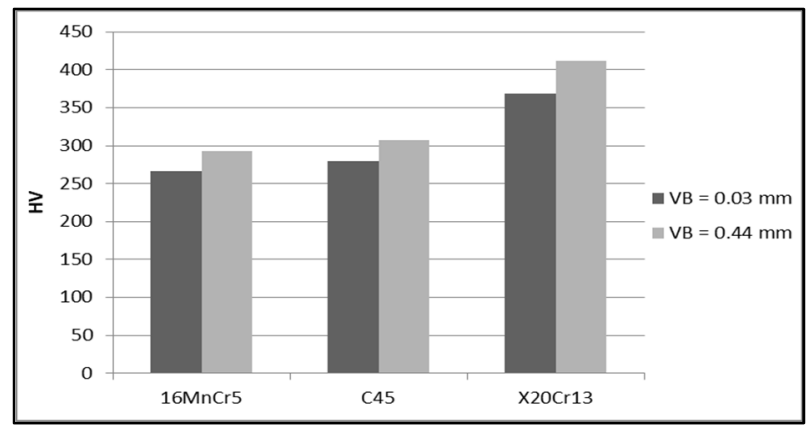

a) $v_{c}=316 \mathrm{~m} / \mathrm{min}(16 \mathrm{MnCr} 5, \mathrm{C45}) ; v_{c}=268 \mathrm{~m} / \mathrm{min}$ (X20Cr13); $f_{z}=0.025 \mathrm{~mm} /$ tooth; $a_{p}=0.05 \mathrm{~mm}$

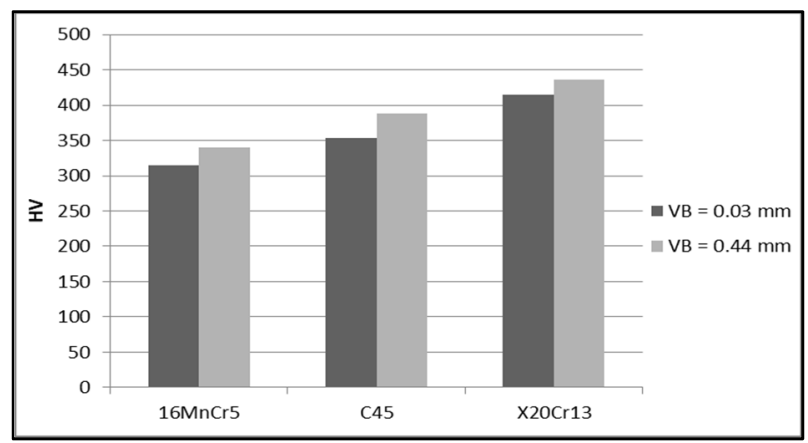

b) $v_{c}=316 \mathrm{~m} / \mathrm{min}(16 \mathrm{MnCr} 5, \mathrm{C45}) ; v_{c}=268 \mathrm{~m} / \mathrm{min}$ (X20Cr13); $f_{z}=0.025 \mathrm{~mm} /$ tooth; $a_{p}=0.5 \mathrm{~mm}$

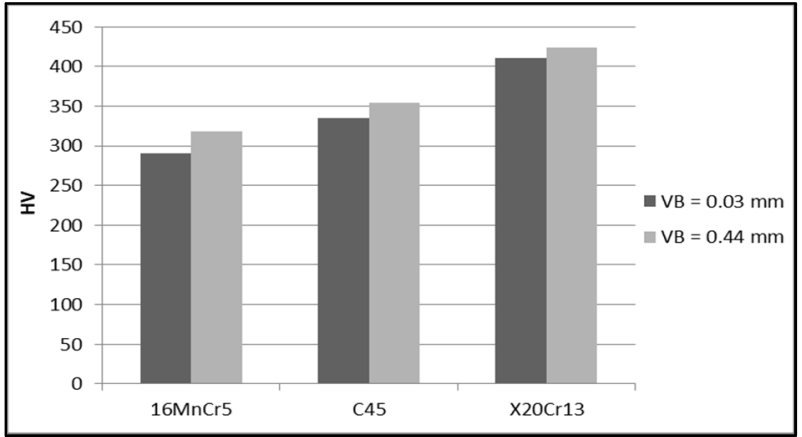

c) $v_{c}=316 \mathrm{~m} / \mathrm{min}(16 \mathrm{MnCr} 5, \mathrm{C45}) ; v_{c}=268 \mathrm{~m} / \mathrm{min}$ (X20Cr13); $f_{z}=0.04 \mathrm{~mm} /$ tooth; $a_{p}=0.05 \mathrm{~mm}$

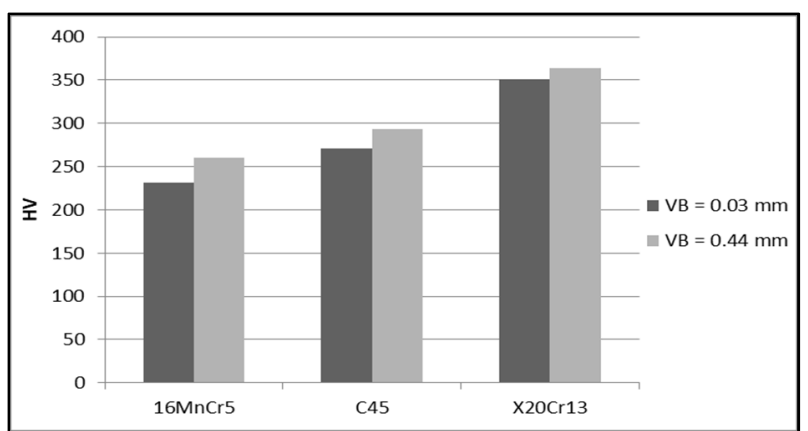

d) $v_{c}=158 \mathrm{~m} / \mathrm{min}(16 \mathrm{MnCr} 5, \mathrm{C45}) ; v_{c}=134 \mathrm{~m} / \mathrm{min}$ $(X 20 \mathrm{Cr} 13) ; f_{z}=0.025 \mathrm{~mm} /$ tooth; $a_{p}=0.05 \mathrm{~mm}$

Fig. 6 Effect of the VB tool wear on the microhardness of the machined surface $H V$

After milling with worn cutting inserts (VB = $0.44 \mathrm{~mm}$ ), a similar 2-fold increase in the cutting speed led to an increase in the microhardness of structural steel $16 \mathrm{MnCr} 5$ by $13 \%$ and structural steel $\mathrm{C} 45$ by $5 \%$ (Fig. $5 b)$. After milling with worn cutting inserts ( $\mathrm{VB}=$ $0.44 \mathrm{~mm}$ ), a similar increase in the cutting speed led to an increase in the microhardness of stainless steel X20Cr13 by $13 \%$ (Fig. $5 b$ ).

The tests showed that the increase in the wear of the cutting insert VB from $0.03 \mathrm{~mm}$ to $0.44 \mathrm{~mm}$ when milling structural steels $16 \mathrm{MnCr} 5$ and $\mathrm{C} 45$ at the cutting speed of $v_{c}=316 \mathrm{~m} / \mathrm{min}$ and milling stainless steel X20Cr13 at $v_{c}$ $=268 \mathrm{~m} / \mathrm{min} ; f_{z}=0.025 \mathrm{~mm} /$ tooth; $a_{p}=0.05 \mathrm{~mm}$ led to an increase in the microhardness of structural steel $16 \mathrm{MnCr} 5$ by $10 \%$, structural steel $\mathrm{C} 45$ by $10 \%$ and stainless steel X20Cr13 by $12 \%$ (Fig. 6a).

A similar increase in the wear of the cutting insert VB when milling structural steels $16 \mathrm{MnCr} 5$ and $\mathrm{C} 45$ at the cutting speed of $v_{c}=316 \mathrm{~m} / \mathrm{min}$ and milling stainless steel $\mathrm{X} 20 \mathrm{Cr} 13$ at $v_{c}=268 \mathrm{~m} / \mathrm{min} ; f_{z}=0.025 \mathrm{~mm} /$ tooth; $a_{p}=$ $0.5 \mathrm{~mm}$ led to an increase in the microhardness of structural steel $16 \mathrm{MnCr} 5$ by $8 \%$, structural steel $\mathrm{C} 45$ by $10 \%$ and stainless steel X20Cr13 by $5 \%$ (Fig. 6b).

Increasing the wear of the cutting insert $\mathrm{VB}$ from $0.03 \mathrm{~mm}$ to $0.44 \mathrm{~mm}$ when milling structural steels $16 \mathrm{MnCr} 5$ and $\mathrm{C} 45$ at the cutting speed of $v_{c}=316 \mathrm{~m} / \mathrm{min}$ and milling stainless steel X20Cr13 at $\mathrm{v}_{\mathrm{c}}=268 \mathrm{~m} / \mathrm{min} ; f_{z}$ $=0.04 \mathrm{~mm} /$ tooth; $a_{p}=0.05 \mathrm{~mm}$ led to an increase in the microhardness of structural steel $16 \mathrm{MnCr} 5$ by $10 \%$, structural steel $\mathrm{C} 45$ by $6 \%$ and stainless steel $\mathrm{X} 20 \mathrm{Cr} 13$ by 3\% (Fig. 6c).

A similar increase in VB when milling structural 
steels $16 \mathrm{MnCr} 5$ and $\mathrm{C} 45$ at the cutting speed of $v_{c}=$ $158 \mathrm{~m} / \mathrm{min}$ and stainless steel X20Cr13 at $\mathrm{v}_{\mathrm{c}}=$ $134 \mathrm{~m} / \mathrm{min} ; f_{z}=0.025 \mathrm{~mm} /$ tooth; $a_{p}=0.05 \mathrm{~mm}$ led to an increase in the microhardness of structural steel $16 \mathrm{MnCr} 5$ by $12 \%$, structural steel $\mathrm{C} 45$ by $8 \%$ and stainless steel X $20 \mathrm{Cr} 13$ by $4 \%$ (Fig. $6 \mathrm{~d}$ ).

It should be noted that it is possible to simultaneously increase the microhardness of the machined surface, both by creating optimal cutting conditions and by using a worn tool.

Thus, increasing the depth of cut $a_{p}$ by 10 times, from $0.05 \mathrm{~mm}$ to $0.5 \mathrm{~mm}$, when milling with worn cutting inserts $(\mathrm{VB}=0.44 \mathrm{~mm})$ led to an increase in the microhardness of structural steel $16 \mathrm{MnCr} 5$ by $28 \%$, structural steel C45 by $39 \%$ and stainless steel X20Cr13 by $18 \%$ (Fig. $3)$.

It was found that the increase in feed $f_{z}$ by $60 \%$, from $0.025 \mathrm{~mm} /$ tooth to $0.04 \mathrm{~mm} /$ tooth, when milling with worn cutting inserts ( $\mathrm{VB}=0.44 \mathrm{~mm}$ ) led to an increase in the microhardness of structural steel $16 \mathrm{MnCr} 5$ by $19 \%$, structural steel C45 by $27 \%$ and stainless steel X20Cr13 by $15 \%$ (Fig. 4 ).

A 2-fold increase in cutting speed $v_{c}$, from $158 \mathrm{~m} / \mathrm{min}$ to $316 \mathrm{~m} / \mathrm{min}$, led to an increase in the microhardness of structural steel $16 \mathrm{MnCr} 5$ by $27 \%$, and of structural steel C45 by $13 \%$ after milling with worn cutting inserts (VB $=0.44 \mathrm{~mm}$ ). A 2-fold increase in the cutting speed of $v_{c}$, from $134 \mathrm{~m} / \mathrm{min}$ to $268 \mathrm{~m} / \mathrm{min}$, led to an increase in the microhardness of X20Cr13 stainless steel by $17 \%$ after milling with worn cutting inserts $(\mathrm{VB}=0.44 \mathrm{~mm}$ ) (Fig. $5)$.

\section{Conclusion}

The conducted tests have demonstrated that one can control the quality of the machined surface during face milling of structural and stainless steels. It was found that the increase in the depth of cut when milling with new cutting inserts led to an increase in the microhardness of steels by $18-23 \%$ and with worn cutting inserts by $6-$ $26 \%$. The increase in feed when milling with new cutting inserts led to an increase in the microhardness by $9-11 \%$ and with worn cutting inserts by $5-15 \%$. The increase in cutting speed when milling with new cutting inserts led to an increase in the microhardness by $3-15 \%$ and with worn cutting inserts by $5-13 \%$. It means that it is possible to achieve a favourable increase in the microhardness of the machined surface by changing the cutting modes and by using a tool with an average wear.

\section{Acknowledgement}

This article is related to the investigation on the Specific University Research Projects which are supported by the Ministry of Education (MSMT) of the Czech Republic.

\section{References}

[1] HUGHES, J., SHARMAN, A., RIDGWAY, K. (2006). The effect of cutting tool material and edge geometry on tool life and workpiece surface integrity. In: Proceedings of the Institution of Mechanical Engineers; Vol.2, pp. 93-107

[2] BORDINASSI, E., STIPKOVIC, M., BATALHA, G., DELIJAICOV, S., LIMA, N. (2006). Superficial integrity analysis in a super duplex stainless steel after turning. In: Journal of Achievements in Materials and Manufacturing Engineering. Vol.18, pp. 335-338

[3] ZHOU, J., BUSHLYA, V., PENG, R. L., STAHL, J-E. (2012). Identification of subsurface deformation in machining of Inconel 718. In: Applied Mechanics and Materials. Vol. 117-119, pp. 16811688.

[4] OOsthuizEN, G., NUNCO, K., CONRADIE, P., DIMITROV, D. (2016). The effect of cutting parameters on surface integrity in milling Ti6Al4V. In: South African Journal of Industrial Engineering. Vol. 27(4), pp. 115-123.

[5] XIAOHONG, L., ZHENYUAN, J., YANJUN, L., YIXUAN, F., STEVEN, L. (2017). Predicting the surface hardness of micro-milled nickel-base superalloy Inconel 718. In: The International Journal of Advanced Manufacturing Technology.

[6] SOO, S.L., HOOD, R., ASPINWALL, D.K., VOICE, W.E., SAGE, C. (2011). Machinability and surface integrity of RR1000 nickel based superalloy. In: CIRP Annals. Vol. 60 (1), pp. 89-92.

[7] KISHAWY, H.A., HOSSEINI, A., MOETAKEFIMANI, B., ASTAKHOV, V.P. (2012). An energy based analysis of broaching operation: Cutting forces and resultant surface integrity. In: CIRP Annals. Vol. 61 (1), pp. 107-110.

[8] Soo, S.L., Khan, S.A., Aspinwall, D.K., Harden, P., Mantle, A., Kappmeyer, G., Pearson, D., M'Saoubi, R. (2016). High speed turning of Inconel 718 using PVD-coated PCBN tools. In: CIRP Annals. Vol. 65 (1), pp. 89-92.

[9] JERSAK, J., KAPLAN, F., (2015). Comparison of the influence of process fluids on tool life in face milling, Manufacturing Technology, 15(6), pp. 977-984

[10] POPOV, A., SCHINDELARZ, R., (2017). Effect of hydraulic oil entering the cutting fluid on the tool life and roughness in milling of stainless steel. Manufacturing Technology, 17(3), pp. 364-369

[11] POPOV, A., BABAK, S., (2017). The effect of the tool wear on the correlation of forces on the face and flank surfaces of the cutting tool. Manufacturing Technology, 17(3), pp. 283-287 